\title{
PENGARUH CITRA MEREK TERHADAP LOYALITAS KONSUMEN PRODUK SEPATU MEREK VANS DI KOTA PALU (STUDI PADA MAHASISWA UNIVERSITAS TADULAKO)
}

\author{
Risqi Awliyah Kartini \\ Rahmat Mubaraq \\ Johnny Tanamal \\ Program Studi S1 Manajemen Fakultas Ekonomi Universitas Tadulako \\ Email: Risqiawliyahkartini@gmail.com
}

\begin{abstract}
Independent variables used in this study are corporate image, user image, product image, while the dependent variable is consumer loyalty. The type of research used in this research is descriptive causal method. The sample used in this research is as much as 80 respondents with the form of sampling using purposive sampling technique. Data analysis method used in this research is multiple regression method. The results showed that the brand image consisting of corporate image, user image, and product image influence on consumer loyalty.
\end{abstract}

Keywords: Brand Image, Corporate Image, User Image, Product Image Loyalty

\begin{abstract}
Abstrak
Variabel independen yang digunakan dalam penelitian ini adalah citra perusahaan, citra pemakai, citra produk, sedangkan variabel dependen adalah loyalitas konsumen.Jenis penelitian yang digunakan dalam penelitian ini adalah metode deskriptif kausal.Sampel yang digunakan pada penelitian ini yaitu sebanyak 80 responden dengan bentuk pengambilan sampel menggunakan teknik purposive sampling.Metode analisis data yang digunakan dalam penelitian ini adalah metode regresi berganda. Hasil penelitian menunjukkan bahwa citra merek yang terdiri dari citra perusahaan, citra pemakai, dan citra produk berpengaruh terhadap loyalitas konsumen.Kata Kunci: citra merek, citra perusahaan, citra pemakai, citra produk loyalitas.
\end{abstract}

\section{PENDAHULUAN}

Citra merek merupakan salah satu faktor untuk membangkitkan loyalitas pelanggan terhadap suatu merek tertentu dari produk yang ditawarkan, dimana dalam persaingan bisnis yang sangat kompetitif saat ini, kelangsungan hidup perusahaan tergantung pada pelanggan yang setia (loyal).Pelanggan merupakan faktor penting yang harus diperhatikan oleh perusahaan, karena pelanggan merupakan aset yang dapat menentukan keberhasilan untuk mencapai tujuan perusahaan.Loyalitas bermanfaat bagi perkembangan jangka panjang perusahaan.Loyalitas konsumen memiliki beberapa keuntungan, yaitu dimana biaya pemasaran menjadi berkurang karena biaya mempertahankan pelanggan lebih murah daripada biaya untuk mencari pelanggan baru (Griffin, 2005).

Saat ini mahasiswa dan mahasiswi di Universitas Tadulako sangat memperhatikan perkembangan fashion yang sedang populer. Fashion yang harus mereka pakai setiap harinya mencerminkan diri dan status sosial mereka. Mulai dari ujung kepala hingga ujung kaki menggunakan produk bermerek nasional hingga yang bermerek internasional, mereka berusaha mendapatkannya agar tampil dengan percaya diri dan nyaman. Merek bukan hanya sekedar simbol, gambar, atau tanda yang tak berarti. Merek merupakan identitas sebuah produk yang dapat dijadikan sebagai alat apakah produk itu baik dan berkualitas. Berbagai macam fashion yang dikenakan mahasiswa dan mahasiswi di Universitas Tadulako, sepatu merupakan bagian fashion yang sangat berpengaruh dalam gaya hidup, sehingga sepatu yang di kenakan pun bervariasi mereknya. Seperti merek sepatu vans, converse, nike, adidas, dan berbagai merek sepatu lainnya yang saat ini sedang populer dikalangan mahasiswa dan mahasiswi di Universitas Tadulako. Banyaknya berbagai merek sepatu yang beredar di pasaran mengakibatkan perusahaan harus menjaga loyalitas konsumen meskipun hal itu bukanlah hal yang mudah. Loyalitas 
Kartini, R.A.

merek adalah kondisi dimana konsumen mempunyai sikap positif terhadap sebuah merek, mempunyai komitmen pada merek tersebut dan termaksud meneruskan pembeliannya dimasa yang akan mendatang (Dharmmesta, 2000:92).Disadari bahwa mencari atau menjaring pelanggan baru itu jauh lebih sulit, sehingga para produsen cenderung untuk mempertahankan pelanggan lama.

Usaha untuk mencapai loyalitas konsumen terhadap suatu merek, perusahaan sangat tergantung pada kemampuannya dalam mengelola faktor-faktor yang mempengaruhi loyalitas merek tersebut, seperti faktor yang berupa citra merek. Citra merek didefinisikan sebagai suatu kesan yang dimiliki oleh pelanggan maupun publik terhadap suatu merek sebagai suatu refleksi atas evaluasi merek yang bersangkutan (Sitinjak, 2006:38). Jika para konsumen merasakan citra merek yang bagus, maka akan mendorong mereka melakukan keputusan pembelian terhadap suatu produk dengan merek tertentu, meningkatkan pembelian bahkan menimbulkan keinginan untuk merekomendasikan merek tersebut dan juga menceritakan hal yang baik mengenai merek tersebut terhadap orang lain. Merek yang kuat akan sangat mempengaruhi perilaku konsumen. Oleh karena itulah menurut Tjiptono (2008), citra merek memiliki 3 variabel pendukung, yaitu : Citra Perusahaan, Citra Pemakai dan Citra Produk.

Vans adalah sebuah perusahaan Amerika yang berbasis di California, selain sepatu perusahaan ini juga memproduksi pakaian, hoodies, kaos kaki, ransel, topi, T-shirt, dan lain-lain. Vans menawarkan produk dengan harga terjangkau dan tanpa kompromi dalam hal kualitas. Vans adalah salah satu di antara beberapa perusahaan sepatu yang telah mencapai pertumbuhan yang luar biasa dalam waktu yang lebih singkat. Adanya berbagai merek sepatu, akan berdampak pula pada ketatnya persaingan untuk mendapatkan konsumen. Melalui persaingan yang begitu ketat dengan merek pesaing lainnya, maka perlunya diperhatikan mengenai citra merek, karena fenomena yang terjadi bahwa volume penjualan sepatu merek vans dalam tahun terakhir mengalami penurunan, sehingga dengan adanya permasalahan tersebut maka perusahaan perlu memperhatikan citra merek, melalui citra perusahaan,citra pemakai dan citra produk.

Salah satu toko sepatu yang menjual Vans di kota Palu adalah Supreme store. Supreme store adalah sebuah toko yang berdiri sejak pertengahan tahun 2014. Usaha bisnis yang berada di pusat pembelanjaan yaitu Palu Grand Mall.Produk-produk yang ada di supreme store merupakan produk bermerk yang sudah memiliki komunitas dan penggemarnya masing-masing seperti Vans, Converse, dan adidas. Vans juga tersedia di Enin store, Loving store, Boost store, dan lain-lain.

Penjualan sepatu merek Vans di Kota Palu selama tahun 2015-2016 berfluktuasi, penjualan tertinggi terjadi pada tahun 2016 sebesar 256 unit dan penjualan terendah terjadi pada tahun 2015 sebesar 220 unit. Penurunan pejualan karena semakin ketatnya persaingan di segmen ini yang melibatkan merek sepatu lainnya seperti converse dan adidas.Melihat trend penjualan sepatu, tentunya dengan citra merek yang dimiliki Vans, maka bukan hal yang tidak mungkin untuk menguasai pasar industri sepatu di kota Palu khususnya di kalangan mahasiswa dan mahasiswi. Agar dapat bertahan dalam persaingan, Vans dituntut untuk merebut perhatian konsumen dan membangun serta mempertahankan loyalitas konsumennya. Loyalitas konsumen saat ini menjadi penentu keberhasilan suatu perusahaan dalam menjalankan usahanya, karena dengan terciptanya loyalitas konsumen, maka perusahaan otomatis mampu tetap survive di tengah persaingan.

Seiring dengan perkembangan persaingan antar produk sepatu dengan berbagai macam keunggulan yang bertujuan untuk menaikkan penjualan, meraih kembali pasar yang telah menurun, dan untuk mempertahankan pasar yang telah diperolehnya adalah tantangan yang harus dihadapi.Tujuan penelitian adalah untuk mengetahui pengaruh citra merek yang terdiri dari citra perusahaan, citra pemakai, dan citra produk terhadap loyalitas konsumen produk sepatu merek vans di kota Palu. 


\section{KAJIAN LITERATUR DAN PENGEMBANGAN HIPOTESIS}

\section{Citra Merek}

Ciri merek dapat dianggap sebagai jenis asosiasi yang muncul dalam benak konsumen ketika mengingat suatu merek tertentu. Asosiasi tersebut secara sederhana dapat muncul dalam bentuk pemikiran atau citra tertentu yang dikaitkan suatu merek, sama halnya ketika kita berpikir tentang orang lain. Asosiasi ini dapat dikonseptualisasikan berdasarkan jenis, dukungan, kekuatan, dan keunikan.Jenis asosiasi merek, meliputi atribut, manfaat, dan sikap.Atribut terdiri dari Atribut yang berhubungan dengan produk, misalnya desain, warna, ukuran, dan atribut yang berhubungan dengan produk, misalnya harga, pemakai, dan citra penggunaan.Sedangkan manfaat, mencakup manfaat secara fungsional, manfaat secara simbolis, dan manfaat berdasarkan pengalaman (Sulistian, 2011:32).

Definisi citra merek menurut Kotler \& Keller (2012:32) sebagai seperangkat keyakinan, ide, dan

kesan, yang dimiliki oleh seseorang terhadap suatu merek, karena itu sikap dan tindakan konsumen terhadap suatu merek sangat ditentukan oleh citra merek tersebut. Citra merek merupakan syarat dari merek yang kuat Simamora (2008:33) mengatakan citra merek adalahpersepsi yang relatif konsisten

dalam waktu jangka panjang. Sehingga tidak mudah untuk membentuk citra, citra sekali terbentuk akan sulit untuk mengubahnya. Citra yang dibentuk harus jelas dan memiliki keunggulan bila dibandingkan dengan pesaingnya, saaat perbedaan dan keunggulan merek dihadapkan dengan merek lain.

Menurut Tjiptono (2008:22) Komponen citra merek (brand image) terdiri atas tiga bagian, yaitu 1) Citra perusahaan (corporate image) yaitu sekumpulan asosiasi yang dipersepsikan konsumen terhadap perusahaan yang membuat suatu barang/jasa. Meliputi: kredibilitas perusahaandan popularitas perusahaan. 2) Citra Pemakai(Userimage) yaitu sekumpulan asosiasi yang dipersepsikan oleh konsumen terhadap pemakai yang menggunakan suatu barang/jasa. Meliputi:gaya hidup atau kepribadian dan kelas sosialnya. 3) Citra produk (product image) yaitu sekumpulan asosiasi yang dipersepsikan konsumen terhadap suatu barang/jasa. Meliputi: atribut dari produk, jaminan kualitas produk serta penawaran produk.

\section{Loyalitas Konsumen}

Menganalisa loyalitas konsumen akan lebih berhasil apabila mampu memahami aspek psikologis manusia. Persepsi merupakan salah satu aspek tersebut dan sebelum presepsi konsumen terbentuk terhadap suatu objek, dalam hal ini kualitas, harga, dan suasana toko merupakan faktor yang memotivasi konsumen dalam suatu produk. Konsumen mempunyai rasa suka dan tidak suka setelah mereka membeli produk dan kemudian persepsi terbentuk dan akan menentukan perilaku terhadap merek produk. Karena dalam persepsi menjelaskan evaluasi kognitif, perasaan emosional, dan kecenderungan tindakan yang menguntungkan (Kartawidjaja dalam Nugroho, 2011:16).

Loyalitas konsumen terhadap suatu barang atau jasa yang ditawarkan oleh suatu perusahaan yang tercermin dari kebiasaan konsumen dalam melakukan pembelian barang atau jasa secara terus menerus harus selalu diperhatikan oleh perusahaan atau produsen.Bagi perusahaan, loyalitas konsumen dapat memberikan nilai yang tinggi bagi inisiatif kepedulian para pelanggan, yaitu lebih mudah dan lebih murah untuk mempertahankan pelanggan kunci, daripada menarik pelanggan baru yang loyalitasnya belum terbukti.Perusahaan perlu mengamati loyalitas konsumen untuk dapat memenuhi keinginan dan kebutuhan konsumen serta tercapainya tujuan suatu barang atau jasa tersebut secara terus menerus, kebiasaan ini termotivasi sehingga sulit dirubah dan sering berkabar dalam keterlibatan yang sangat tinggi (Nugroho, 2011:16).

Konsumen dengan loyalitas tinggi akan memberitahukan keunggulan dan kualitas layanan tersebut kepada orang lain bahkan sering memberikan saran untuk menggunakan layanan jasa yang diberikan kepada konsumen. Fullerton dan Taylor (2012) membagi tingkat loyalitas konsumen dalam tiga tahap, antara lain: 
Kartini, R.A.

1. Loyalitas advokasi, merupakan sikap pelanggan untuk memberikan rekomendasi kepada orang lain untuk melakukan pembelian ulang terhadap produk atau jasa. Loyalitas advokasi pada umumnya disertai dengan pembelaan konsumen terhadap produk atau jasa yang dipakai.

2. Loyalitas repurchase, yaitu loyalitas pelanggan berkembang pada perilaku pembelian pelanggan terhadap layanan baru yang di keluarkan oleh suatu perusahaan, yang di tunjukan dengan keinginan dengan keinginan untuk membeli kembali.

3. Loyalitas paymore, yaitu loyalitas pelanggan untuk kembali melakukan transaksi untuk menggunakan produk atau jasa yang telah dipakai oleh konsumen tersebut dengan pengorbanan yang lebih besar.

Konsumen merekomendasikan loyalitas mereka pada suatu perusahaan atau merek dengan membeli berulang kali, membeli produk atau jasa tambahan perusahaan tersebut, dan merekomendasikannya pada orang lain. Hal tersebut diperkuat dengan pernyataan dari Griffin (2005:31), yang menyatakan bahwa karakteristik pelanggan yang loyal antara lain:

1. Melakukan pembelian berulang secara teratur. Pelanggan yang loyal adalah mereka yang melakukan pembelian barang ataupun jasa secara teratur bahkan mereka akan tetap membeli meskipun harganya mengalami kenaikan.

2. Membeli antar lini produk atau jasa. Pelanggan yang loyal bukan hanya membeli satu jenis produk atau jasa saja dari sebuah perusahaan, melainkan mereka juga membeli produk ataupun jasa tambahan yang disediakan oleh perusahaan tersebut.

3. Menunjukan kekebalan terhadap tarikan dari pesaing. Para konsumen yang loyal selalu menolak apabila ditawari produk atau jasa dari perusahaan lain (pesaing).Mereka sudah memiliki kecintaan tersendiri terhadap produk atau jasa yang telah digunakan.

4. Mereferensikan kepada orang lain. Konsumen yang loyal selalu ingin mereferensikan suatu produk atau jasa yang digunakannya kepada orang lain, baik kepada teman maupun saudara. Mereka selalu mempengaruhi orang lain untuk menggunakan produk atau jasa yang sama dengan selalu menceritakan kelebihan produk atau jasa yang dia gunakan sampai orang tersebut mencoba menggunakannya.

\section{Hubungan Antara Citra Merek Dan Loyalitas Konsumen}

Hubungan antara citra merek dengan loyalitas konsumen terletak pada keinginan dan pilihan konsumen (preference) atas suatu merek adalah merupakan sikap konsumen.Sikap konsumen terhadap merek tertentu sering mempengaruhi apakah konsumen akan loyal atau tidak. Resepsi yang baik dan kepercayaan konsumen akan kepercayaan merek tertentu akan menciptakan minat beli konsumen dan bahkan meningkatkan loyalitas konsumen terhadap produk tertentu. Teori penghubung antara citra merek dengan loyalitas konsumen dikutip dari Rangkuti (2002) yang mengatakan apabila konsumen beranggapan bahwa merek tertentu secara fisik berbeda dari merek pesaing, citra merek tersebut akan melekat secara terus menerus sehingga dapat membentuk kesetiaan terhadap merek tertentu yang disebut dengan loyalitas merek.

\section{Hipotesis}

1. Citra merek yang terdiri dari citra perusahaan, citra pemakaidan citra produksecara serempak berpengaruh signifikan terhadap loyalitas konsumen produk sepatu merek Vans di Kota Palu.

2. Variabel citra perusahaan berpangaruh signifikan terhadap loyalitas konsumen produk sepatu merek Vans di Kota Palu.

3. Variabel citra pemakaiberpengaruh signifikan terhadap loyalitas konsumen produk sepatu merek Vans di Kota Palu.

4. Variabel citra produk berpengaruh signifikan terhadap loyalitas konsumen produk sepatu merek Vans di Kota Palu. 


\section{METODE PENELITIAN Jenis Penelitian}

Jenis penelitian yang digunakan dalam penelitian ini adalah Deskriptif Kausal.Sugiyono (2014:53) Penelitian deskriptifadalah rumusan masalah yang berkenaan dengan pertanyaan terhadap keberadaan variabel mandiri, baik hanya satu variabel atau lebih (variabel mandiri adalah variabel yang berdiri sendiri, bukan variabel independen, karena kalau variabel independen selalu dipasangkan dengan varabel dependen).Penerapannya merupakan interpertasi dari hasil statistik atau yang diperoleh dari perhitungan kuantitatif mengenai citra merek terhadap loyalitas konsumen produk sepatu merek Vans di Kota Palu.

\section{Metode Pengumpulan Data}

Menurut Sugiyono (2014:401) metode pengumpulan data merupakan langkah yang paling utama dalam penelitian, karena tujuan utama dari penelitian adalah mendapatkan data. Tanpa mengetahui teknik pengumpulan data, maka peneliti tidak akan mendapatkan data yang memenuhi standar data yang ditetapkan. Adapun teknik pengumpulan data yang digunakan dalam penelitian ini:

1) Kuesioner merupakan teknik pengumpulan data yang dilakukan dengan cara memberi seperangkat pertanyaan atau pernyataan tertulis kepada responden untuk dijawabnya. Kuesioner digunakan untuk mengetahui pendapat responden yakni menjawab dengan cara memberi tanda tertentu pada alternatif jawaban yang disediakan. Kuesioner diberikan kepada responden secara langsung atau melalui email karena luasnya lingkup penelitian.

2) Peneliti melakukan studi kepustakaan dengan cara menganalisis berbagai literatul yang ada seperti buku, skripsi, dan jurnal, yang berkaitan dengan variabel penelitian. Selain itu, peneliti juga menggunakan dokumen-dokumen referensi pendukung seperti artikel, majalah, dsb. Peneliti juga melakukan penjelajahan internet untuk melakukan pencarian data dan informasi yang terkait dengan penelitian ini.

3) Wawancara, yaitu komunikasi atau pembicaraan dua arah yang dilakukan oleh peneliti dan responden untuk menggali informasi yang relevan dengan tujuan penelitian.

\section{Metode Analisis \\ Analisis Deskriptif}

Nisfiannoor (2009:4), menjelaskan analisis deskriptif digunakan untuk mengumpulkan, meringkas, menyajikan, dan mendeskripsikan data sehingga dapat memberikan informasi yang berguna.Data yang disajikan dalam statistika deskriptif biasanya dalam bentuk ukuran pemusatan data (mean, median, dan modus), ukuran penyebaran data (standar deviasi dan varians), tabel, serta grafik (histogram, pie, dan bar). Analisis deskriptif dalam penelitian ini bertujuan untuk menganalisa data dengan cara mendeskripsikan atau menggambarkan empiris data yang telah dikumpulkan dari responden melalui kuesioner penelitian dalam bentuk berbagai karakteristik responden secara keseluruhan.

\section{Analisis Regresi Berganda}

Tujuan penelitian ini adalah untuk mengukur dan menganalisis besarnya pengaruh citra merek terhadap loyalitas konsumen produk sepatu merek Vans di Kota Palu,maka menggunakan alat analisis statistic parametric regresi linear berganda (Multiple Regression Analisis).Menurut pendapat yang dijelaskan oleh Sugiyono (2014:277) bahwa model umum bentuk persamaan alat analisis statistic parametric regresi linear berganda dapat digambarkan sebagai berikut:

$\mathrm{Y}=\mathrm{a}+\quad+\mathrm{b}_{3} \mathrm{X}_{3}+\mathrm{b}_{4} \mathrm{X}_{4}+\mathrm{e}$

\section{Pengujian Hipotesis Pertama (Uji Simultan/Uji F)}

Uji ini digunakan untuk mengetahui seluruh variabel independen secara simultan mempunyai pengaruh yang signifikan terhadap variabel. Dimana F (hitung) > F (tabel), maka H1 diterima atau 
Kartini, R.A.

secara bersama-sama variabel bebas dapat menerangkan variabel terikatnya secara serentak. Sebaliknya apabila $\mathrm{F}$ (hitung) < F(tabel), maka H0 diterima atau secara bersama-sama variabel bebas tidak memiliki pengaruh terhadap variabel terikat. Untuk mengetahui signifikan atau tidak pengaruh secara bersama-sama variabel bebas terhadap variabel terikat maka digunakan probability sebesar 5\% $(\alpha=0,05)$. Yaitu dengan ketentuan sebagi berikut:

1. Jika sig $>\alpha ́ \alpha(0,05)$, maka hipotesis ditolak.

2. Jika sig $<\alpha ́ \alpha(0,05)$, maka hipotesis diterima.

\section{Pengujian Hipotesis Kedua (Uji Parsial/Uji t)}

Uji t digunakan untuk mengetahui apakah suatu variabel secara parsial berpengaruh nyata atau tidak, maka digunakan uji t atau $t$-student. Uji t dapat dilakukan dengan beberapa cara, diantaranya menentukan daerah kritis. Daerah kritis ditentukan oleh nilai t (tabel) dengan derajat kebebasan yaitu $\mathrm{n}-\mathrm{k}$, dengan taraf $\alpha$ pengujian ini untuk mengetahui pengaruh masing-masing variabel independen secara parsial berpengaruh signifikan terhadap variabel dependen di lakukan dengan pengujian Uji t, dimana derajat signifikan yang digunakan adalah $\alpha=0,05$ dengan bentuk pengujian sebagai berikut:

1. Jika nilai signifikan (sig. $\mathrm{t}$ ) $\leq \alpha=0,05$, artinya masing-masing variabel independen secara parsial berpengaruh signifikan terhadap loyalitas konsumen produk sepatu merek Vans di Kota Palu, sehingga dapat dinyatakan bahwa hipotesis yang diajukan dalam penelitian ini masing-masing diterima secara parsial.

2. Jika nilai signifikan (sig. $\mathrm{t}$ ) $\geq \alpha=0,05$, hal ini artinya masing-masing variabel independen secara parsial berpengaruh tidak signifikan terhadap terhadap loyalitas konsumen produk sepatu merek Vans di Kota Palu,sehingga dapat dinyatakan bahwa hipotesis yang diajukan dalam penelitian ini masing-masing diterima secara parsial.

\section{HASIL DAN PEMBAHASAN}

\section{Hasil Penelitian}

\section{Deskripsi Hasil Penelitian}

\section{Citra Perusahaan $\left(\mathbf{X}_{1}\right)$}

Nilai mean tertinggi pada variabel citra perusahaan dengan indikator yaitu kredibilitas perusahaan (X1.1) diperoleh nilai mean sebesar 4,23. Artinya, adanya kepercayaan mahasiswa terhadap perusahaan Vans, kepercayaan ini dikarenakan produk sepatu merek Vans sudah tersebar diseluruh dunia sehingga dapat mempengaruhi tingkat kepercayaan mahasiswa. Kemudian indikator dengan nilai mean terendah pada indikator popularitas perusahaan (X1.2) diperoleh nilai mean sebesar 4,21. Artinya, persepsi mahasiswa bahwa masih ada produk sepatu sejenis yang popularitasnya tidak kalah dengan produk sepatu merek Vans.Nilai rata-rata mean sebesar 4,22 dari keseluruhan indikator pada variabel citra perusahaan. Artinya, bahwa tanggapan responden atas pernyataan dari indikator variabel citra perusahaan ditanggapi sangat baik oleh responden.

\section{Citra Pemakai $\left(\mathbf{X}_{2}\right)$}

Nilai mean tertinggi pada variabel citra pemakai dengan indikator yaitu agar mendapat perhatian (X2.3) dengan nilai mean sebesar 4,52. Artinya, mahasiswa sebagai konsumen akan merasakan mendapatkan perhatian lebih dari teman-temannya jika menggunakan sepatu merek Vans, hal ini merupakan salah satu cara mahasiswa untuk mengaktualisasi dirinnya di kalangan mereka, yang mana ingin tampil lebih dihadapan orang lain. Kemudian indikator yang memperoleh nilai mean terendah sebesar 4,23 yaitu indikator lebih mengikuti perkembangan mode (X2.2), mahasiswa sebagai responden masih menganggap bahwa masih ada produk sepatu sejenis yang juga mengikuti perkembangan mode dan nilai rata-rata mean sebesar 4,38 dari keseluruhan indikator pada variabel 
citra pemakai. Artinya, bahwa tanggapan responden atas pernyataan dari indikator variabel citra pemakai ditanggapi sangat baik oleh responden.

\section{Citra Produk $\left(\mathbf{X}_{3}\right)$}

Nilai mean tertinggi pada variabel citra produk dengan indikator yaitu jaminan bagi konsumen (X3.3), dengan nilai mean sebesar 4,5. Artinya, bahwa dengan tersebarnya distributor-distributor resmi produk sepatu merek Vans membuat konsumen merasa keaslian dari produk sepatu merek Vans terjamin. Kemudian indikator yang memperoleh nilai mean terendah sebesar 4,0 yaitu indikator desain menarik (X3.2), penelitian ini menujukkan bahwa anggapan konsumen terhadap desain produk sepatu merek Vans masih rendah, ini bisa saja disebabkan karena belum lengkapnya desain sepatu merek Vans yang tersedia di indonesia. Konsumen harus mendapatkannya dari luar negri lewat online shop berskala internasional, tentunya dengan harga yang lebih mahal. Nilai rata-rata mean sebesar 4,21 dari keseluruhan indikator pada citra produk mengartikan berarti bahwa tanggapan responden atas pernyataan dari indikator variabel citra produk ditanggapi sangat baik oleh responden.

\section{Loyalitas (Y)}

Nilai mean tertinggi pada variabel merekomendasikan ke orang lain (Y4), diperoleh nilai mean sebesar 4.4. Artinya, bahwa pelanggan yang sudah merasa puas akan produk-produk sepatu merek Vans akan merekomendasikan produk tersebut ke orang lain. Kemudian indikator paling rendah dengan nilai mean hanya sebesar 4,05 yaitu tidak terpengaruh produk lain (Y3). Artinya bahwa mahasiswa yang menjadi responden masih cenderung akan terpengaruh akan produk sepatu merek lain yang sejenis. Nilai rata-rata mean sebesar 4,23 dari keseluruhan indikator pada variabel loyalitas. Artinya bahwa tanggapan responden atas pernyataan dari indikator variabel loyalitas ditanggapi sangat baik oleh responden.

\section{Hasil Pengujian Hipotesis}

Tabel 1.Ringkasan Hasil Uji Regresi Berganda

\begin{tabular}{|c|c|c|c|c|c|}
\hline \multicolumn{6}{|c|}{ Dependen Variabel Y = Loyalitas } \\
\hline \multirow[t]{2}{*}{ Variabel Independen } & \multicolumn{2}{|c|}{$\begin{array}{l}\text { Unstandardized } \\
\text { Coefficients }\end{array}$} & $\begin{array}{c}\text { Standardized } \\
\text { Coefficients }\end{array}$ & $\mathrm{t}$ & Sig \\
\hline & $\mathrm{B}$ & Standar Error & Beta & & \\
\hline $\mathrm{C}=$ Constanta & .294 & .323 & & .911 & .365 \\
\hline Citra perusahaan $\left(\mathrm{X}_{1}\right)$ & .264 & .079 & .304 & 3.341 & .001 \\
\hline Citra pemakai $\left(\mathrm{X}_{2}\right)$ & .931 & .104 & .868 & 8.972 & .000 \\
\hline Citra produk $\left(\mathrm{X}_{3}\right)$ & .230 & .089 & .219 & 2.572 & .012 \\
\hline Multiple $\mathrm{R}=.832$ & & Sig.F & $=.000$ & & \\
\hline $\mathrm{R}$ Square $\left(\mathrm{R}^{2}\right)=.693$ & & $\mathrm{~F}$ & $=57.158$ & & \\
\hline
\end{tabular}

\section{Pengujian Hipotesis Pertama (Uji F)}

Hasil pengujian secara serempak diperoleh angka signifikansi F sebesar 0,000. Angka $0,000<0,05$ oleh karena itu, Ho ditolak dan $\mathrm{H}_{1}$ diterima. Artinya adanya pengaruh signifikan variabel citra merek yang terdiri dari citra perusahaan (X1), citra pemakai (X2), dan citra produk (X3) terhadap loyalitas konsumen produk sepatu merek Vans.

\section{Pengujian Hipotesis (Hasil Uji t)}

1. Variabel Citra Perusahaan $\left(\mathrm{X}_{1}\right)$

Hasil pengujian regresi linier berganda dengan SPSS diperoleh angka signifikansi sebesar 0,001. Angka $0,001<0,05$ oleh karena itu, hipotesis diterima. Hal ini berarti variabel $\mathrm{X}_{1}$ (citra perusahaan) berpengaruh signifikan terhadap variabel Y (loyalitaskonsumen produk sepatu merek Vans di Kota Palu). 


\section{Variabel Citra Pemakai $\left(\mathrm{X}_{2}\right)$}

Hasil pengujian regresi linier berganda dengan SPSS diperoleh angka signifikansi sebesar 0,000. Angka $0,000<0,05$ oleh karena itu, hipotesis diterima. Hal ini berarti variabel $\mathrm{X}_{2}$ (citra pemakai) berpengaruh signifikan terhadap variabel Y (loyalitas konsumenproduk sepatu merek Vans di Kota Palu).

3. Variabel Citra Produk $\left(\mathrm{X}_{3}\right)$

Hasil pengujian regresi linier berganda dengan SPSS diperoleh angka signifikansi sebesar 0,012. Angka $0,012<0,05$ oleh karena itu, hipotesis diterima. Hal ini berarti variabel $\mathrm{X}_{3}$ (citra produk) berpengaruh signifikan terhadap variabel Y (loyalitaskonsumen produk sepatu merek Vans di Kota Palu).

\section{Hasil Analisis Regresi Linear Berganda}

Analisis regresi linear berganda digunakan dalam penelitian ini dengan tujuan untuk mengetahui ada tidaknya pengaruh variabel bebas terhadap variabel terikat.Perhitungan statistik dalam analisis regresi linear berganda yang digunakan dalam penelitian ini adalah dengan menggunakan bantuan program komputer SPSS for Windows versi 16.0.Hasil perhitungan dalam Tabel 1 apabila ditulis dalam bentuk dari persamaan regresinya adalah sebagai berikut:

$\mathrm{Y}=0,294+0.264 \mathrm{X} 1+0.931 \mathrm{X} 2+0.230 \mathrm{X} 3+\mathrm{e}$

1) Nilai Konstanta $Y$ (loyalitas) sebesar 0.294. Artinya, jika nilai variabel citra perusahaan $\left(X_{1}\right)$, citra pemakai $\left(\mathrm{X}_{2}\right)$, dan citra produk $\left(\mathrm{X}_{3}\right)$ bernilai 0, maka variabel dependen loyalitas $(\mathrm{Y})$ sebesar 0.294. Setiap ada kenaikan pada variabel independen maka akan meningkatkan variabel dependen sebesar nilai koefisien beta masing-masing variabel independen.

2) Koefisien regresi variabel citra perusahaan $\left(X_{1}\right)$ sebesar 0,264. Artinya, jika ada kenaikan pada variabel citra perusahaan $\left(\mathrm{X}_{1}\right)$ makaakan meningkakan variabel loyalitas konsumen sebesar 0,264.

3) Koefisien regresi variabel citra pemakai $\left(X_{2}\right)$ sebesar 0,931. Artinya, jika ada kenaikan pada variabel citra pemakai $\left(\mathrm{X}_{2}\right)$ maka akan meningkatkan variabel kepuasan pelanggan sebesar 0,931.

4) Koefisien regresi variabel citra produk $\left(X_{3}\right)$ sebesar 0,230. Artinya,jika ada kenaikan pada variabel citra produk $\left(\mathrm{X}_{3}\right)$ maka akan meningkatkan variabel kepuasan pelanggan sebesar 0,230.

\section{Pembahasan Hasil Penelitian}

\section{Pengaruh Citra Perusahaan Terhadap Loyalitas Konsumen Produk Sepatu Merek Vans di Kota Palu.}

Hasil penelitian menunjukkan bahwa citra perusahaan berpengaruh signifikan terhadap loyalitas.Citra perusahaan adalah sekumpulan asosiasi yang dipersepsikan konsumen terhadap perusahaan yang membuat suatu barang/jasa. Meliputi: kredibilitas perusahaan dan popularitas perusahaan. Hasil penelitian menunjukan bahwa citra perusahaan produk sepatu merek Vans yang terkenal dan merupakan salah satu perusahaan terbesar yang memproduksi sepatu,perusahaan yang memiliki nama besar sebagai perusahaan yang terpercaya dengan produk yang sudah terkenal serta mempunyai jaringan distributor yang tersebar di seluruh dunia, sehingga kredibilitas perusahaan ini dapat diperhitungkan. Ini dibuktikan dengan jawaban responden pada variabel citra perusahaan yang memiliki indikator dengan nilai mean tertinggi yaitu kredibilitas perusahaan perusahaan (X1.1). Hal ini menunjukkan hasil yang sama dari penelitian sebelumnya yang dilakukan oleh Erwina, dkk (2016) yang menyatakan adanya pengaruh positif citra perusahaan terhadap loyalitas.

\section{Pengaruh Citra Pemakai Terhadap Loyalitas Konsumen Produk Sepatu Merek Vans di Kota Palu.}

Hasil penelitian menunjukkan bahwa citra pemakai berpengaruh signifikan terhadap loyalitas. Citra pemakai adalah sekumpulan asosiasi yang dipersepsikan oleh konsumen terhadap pemakai yang menggunakan suatu barang/jasa meliputi:gaya hidup atau kepribadian dan kelas sosialnya. Artinya 
Vans sudah sesuai dengan keseluruhan gaya hidup hedonis konsumen yang mayoritas berasal dari anak muda saat ini dan konsumen akan melakukan pembelian apabila konsumen merasa sepatu merek Vans yang akan dibelinya ini sesuai dengan gaya hidupnya. Citra pemakai mencakup lebih percaya diri saat menggunakan produk sepatu merek Vans, Produk sepatu merek Vans mengikuti perkembangan mode dan menggunakan produk sepatu merek Vans agar mendapat perhatian dari teman-teman.Hasil penelitian ini menunjukan bahwa citra pemakai dapat memberikan kesan positif terhadap konsumen sehingga dapat mempengaruhi loyalitas. Kesan positif,yaitu indikator agar mendapat perhatian (X2.3) yang merupakan nilai mean tertinggi, hal itu menunjukan bahwa konsumen merasa senang jika saat menggunakan produk sepatu merek Vans, ia akan merasa mendapat pujian dari orang lain. Menurut Kotler \&Keller (2012) citra merek adalah seperangkat keyakinan, ide, kesan atau rasa yang dimiliki oleh konsumen terhadap suatu objek. Penelitian ini juga sejalan dengan penelitian Gadau(2016) yang manyatakan bahwa citra pemakai memberikan kesan atau rasa yang unik serta dapat membekas terhadap ingatan konsumen dengan merasa nyaman dan percaya diri saat menggunakan produk body mist The body shop dan dapat mempengaruhi loyalitas konsumen terhadap produk The body shop.

\section{Pengaruh Citra Produk Terhadap Loyalitas Konsumen Produk Sepatu Merek Vans di Kota Palu.}

Hasil penelitian menunjukkan variabel citra produk berpengaruh signifikan terhadap Loyalitas.Citra produk mencakup atribut dari produk, jaminan dari produk dan penawaran produk yang dapat menciptakan loyalitas. Hasil penelitian menunjukan bahwa hadirnya distributor-distributor resmi dari perusahaan produk sepatu merek Vans membuat konsumen merasa bahwa keaslian dari produk sepatu merek Vans lebih terjamin, Ini terbukti dengan nilai mean tertinggi yang didapatkan dari tanggapan responden terhadap indikator tersebut. Selain itu, adanya kesesuaian harga dengan manfaat produk yang diterima oleh konsumen juga dapat memberikan rasa kepuasan dan mendorong loyalitas bagi konsumen.Penelitian ini sejalan dengan penelitian yang dilakukan oleh Pradipta (2012) bahwa adanya pengaruh positif citra pemakai dan citra produk terhadap loyalitas konsumen.

\section{KESIMPULAN DAN SARAN}

\section{Kesimpulan}

1. Citra merek yang terdiri dari citra perusahaan, citra pemakai, dan citra produk secara serempak berpengaruh signifikan terhadap loyalitas konsumen produk sepatu merek Vans di Kota Palu.

2. Citra perusahaan berpengaruh signifikan terhadap loyalitas konsumen produk sepatu merek Vans di Kota Palu..

3. Citra pemakai berpengaruh signifikan terhadap loyalitas konsumen produk sepatu merek Vans di Kota Palu.

4. Citra produk berpengaruh signifikan terhadap loyalitas konsumen produk sepatu merek Vans di Kota Palu.

\section{Saran}

1. Bagi Perusahaan

a) Perusahaan produk sepatu merek Vans sebaiknya selalu menjaga kredibilitas perusahaan agar kepercayaan pelanggan dapat terjaga kepada perusahaan untuk dapat tetap menjadi pilihan produk sepatu terbaik yang dapat membuat pelanggan puas. Menjaga kredibilitas perusahaan dapat di mulai dengan memberikan nilai-nial positif bagi konsumen seperti berusaha untuk menjaga kualitas produk.

b) Pihak perusahaan hanya perlu mengatur dan mengelola produk-produk yang ditawarkan sedemikian rupa lagi maka loyalitas pelanggan akan semakin meningkat. dan untuk mempertahankan yang selama ini sudah terlaksana dengan baik dibutuhkan tindakan langsung 
Kartini, R.A.

berupa penyusunan strategi pasar dalam melihat perkembangan desain seperti apa yang saat ini sedang trend di kalangan masyarakat, sehingga produk sepatu merek Vans tidak kalah dengan produk sepatu merek lain yang juga tidak kalah inovatif dalam menciptakan desain yang menarik.

c) Pihak perusahaan perlu melengkapi ketersediaan jenis sepatu Vans yang ada di indonesia, sehingga konsumen tidak harus membelinya dari luar negri.

d) Untuk mempertahankan loyalitas, disarankan kepada pihakperusahaan untuk melakukan survey pengukuran kepuasan secara berkala sebagai bentuk pengendalian agar kepuasan konsumen tetap terjaga sehingga dapat mendorong terciptanya loyalitas bagi konsumen. Survey ini dapat dilakukan dengan situs web resmi perusahaan, agar semua konsumen di berbagai Negara bisa terjangkau dengan mudah.

2. Bagi Peneliti Selanjutnya

Bagi peneliti selanjutnya yang ingin meneliti atau melanjutkan penelitian ini, disarankan untuk meneruskan atau mengembangkan penelitian ini dengan mencari faktor lain yang dapat mempengaruhi loyalitas seperti faktor atribut produknya dan kualitas pelayanan.

\section{REFERENSI}

Dharmmestha, B. S.(2000). Manajemen Pemasaran: Analisisa Perilaku Konsumen. Yogyakarta: Liberty.

Erwina, Mintarti, dan Nur. (2016). Pengaruh Kualitas Pelayanan dan Citra Perusahaan Terhadap Kepuasan Pelanggan dan Loyalitas Pelanggan Service Center (Studi Pada Pelanggan Samsung Service Center di Kota Malang. Jurnal Ekonomi Bisnis, Volume 1, Nomor 1, Maret 2016, Hal: 90-104.

Fullerton, Gordon dan Taylor, S. (2012).The Role of Commitment in Service Relationship. Ontario: School of Business Acadia University Published.

Gadau, Matias. (2016). Pengaruh Citra Merek (Brand Image) Terhadap Loyalitas Konsumen Produk Body Mist The Body Shop di Ambarukmo Plaza. Yogyakarta: Universitas Sanata Dharma.

Griffin, Jill, (2005). Customer Loyalty: Menumbuhkan dan Mempertahankan Kesetiaan Pelanggan. Jakarta: Erlangga.

Kotler, P.\& Keller, K.L. (2012). Marketing Management (13th ed.). New Jersey: Prentice Hall, Inc. Nisfiannoor, Muhammad. (2009). Pendekatan Statistika Modern Untuk Ilmu Sosial. Jakarta: Salemba Humanika.

Nugroho, Farid Yuniar.(2011). Pengaruh Citra Merek dan Kepuasan Pelanggan Terhadap Loyalitas Konsumen. Yogyakarta: Universitas Pembangunan Nasional Veteran.

Pradipta, Dyah Ayu Anisha. (2012). Pengaruh Citra Merek (Brand Image) Terhadap Loyalitas Konsumen Produk Oli Pelumnas PT. Pertamina (Persero) Enduro 4T di Makassar. Makassar: Universitas Hasanuddin.

Rangkuti, F, (2002). The Power of Brands: Teknik Mengelola Brand Equity dan Strategi Pengembangan Merek + Analisis Kasus dengan SPSS. Jakarta: PT. Gramedia Pustaka Utama.

Simamora, B, (2008). Panduan Riset Perilaku Konsumen. Jakarta: Gramedia Pustaka Utama.

Sitinjak, T, (2006). Kinerja Citra, Sikap, Ekuitas Merek, Kepuasan dan Loyalitas Nasabah Bank BUMN di Jakarta. Jurnal Ekonomi Perusahaan, 35-51.

Sugiyono, (2014).Metode Penelitian Bisnis (Pendekatan. Kuantitatif, Kualitatif, dan R\&D), Cetakan Ke-18.Bandung: CV. Alfabeta.

Sulistian, Ogi. (2011). Pengaruh Brand Image Terhadap Loyalitas Pelanggan Rokok Gudang Garam Filte. Kuningan: Universitas Kuningan.

Tjiptono, Fandy. (2008). Strategi Pemasaran. Yogyakarta: CV. Andi Offset. 